УДК 543.08:665.3

DOI: https://doi.org/10.36910/6775-2313-5352-2019-15-6

${ }^{1}$ I.П. Захаров, д.т.н., ${ }^{2}$ Т.В. Чуніхіна, к.т.н., ${ }^{3}$ В.Ю. Папченко, к.т.н.

${ }^{1}$ Харківський національний університет радіоелектроніки

${ }^{2}$ Національний технічний університет "Харківський політехнічний інститут"

${ }^{3}$ Український науково-дослідний інститут олій та жирів Національної академії аграрних наук України

\title{
ОЦНЮВАННЯ НЕВИЗНАЧЕНОСТІ ВИМІРЮВАНЬ ПРИ ДОСЛІДЖЕННЯХ НАСІННЯ СОНЯШНИКА НОВОЇ ЛІНІЇ
}

Олієжирова галузь є провідною галуззю харчової промисловості Украӥни. Зростаючий за останні роки об'єм виробництва соняшникової олії пояснюється зростанням врожаю та збільшенням вмісту олії у насінні соняшника. У роботі представлені результати дослідження фізико-хімічних показників якості соняшникового насіння нової лінії. Детально розглянуто проиес дослідження одного із фізико-хімічних показників якості насіння сонямника-вмісту олії, із застосуванням методу екстракиії. На прикладі одного із показників якості, вмісту олії у насінні соняшника, показано розрахунок невизначеності вимірювання иього показника.

Ключові слова: насіння соняшника, фізико-хімічні показники якості, метод екстракиії, паралельні вимірювання, невизначеність вимірювання.

Постановка проблеми. Жири тваринного та рослинного походження займають четверту позицію серед груп товарів, які було експортовано Україною у 2018 році.

Україна є світовим лідером 3 виробництва та експорту соняшникової олії. За даними Державної служби статистики України, у січні-липні 2019 року в Україні було вироблено 3,25 млн. тон нерафінованої соняшникової олії, що на 17,3\% перевищує аналогічний період 2018 року. Зростання об'ємів виробництва пояснюється зростанням урожаю та підвищенням вмісту олії у насінні соняшника.

Основні вимоги, що висуваються до соняшникової олії - це вимоги до показників якості та безпеки [1-7].

Ці показники визначаються у спеціалізованих фізико-хімічних лабораторіях, акредитованих на відповідність вимогам стандарту ДСТУ ISO/IEC 17025:2006 [8]. Відповідно до вимог цього стандарту лабораторії повинні мати процедури оцінювання невизначеності вимірювань по кожному виду випробувань. Однак, ця вимога у більшості лабораторій не виконується у зв'язку зі специфікою фізико-хімічних випробувань.

В роботі [9] досліджені особливості оцінювання невизначеності паралельних вимірювань при виконанні кількісного хімічного аналізу. Оцінка невизначеності вимірювання показників якості та безпеки соняшникової олії була проведена у [10].

Метою роботи $\epsilon$ аналіз процедури оцінювання невизначеності вимірювання вмісту олії у насінні соняшника як базового фізико-хімічного показника якості насіння соняшника.

Дослідження фізико-хімічних показників якості насіння соняшника.

У рамках даної роботи були отримані результати досліджень п'яти фізико-хімичних показників якості насіння соняшника нової лінії X $114 \mathrm{~B}$, розробленого Інститутом рослинництва ім. В.Я. Юр'єва НААНУ: вологість, $7.2 \%$; вміст олії у насінні у перерахунку на суху речовину, 40,61 \%; об'ємна маса, 475,07 г; маса 100 одиниць насіння, 42, 95 г; масова частка оболонки у насінні, $32,7 \%$.

Показник якості насіння соняшника “вміст олії” визначався методом екстракції в апараті Сокслета [7].

Відповідно до [7] вміст олії у звільненому від сміття й підсушеному насінні у відсотках обчислюють за формулою:

$$
X=\frac{\left(m-m_{1}\right)}{m_{2}} \cdot 100 \%
$$

де $m$ - маса колби з олією, г; $m_{1}$ - маса порожньої колби, г; $m_{2}-$ наважка підсушеного насіння в екстракційному патроні, г.

Для розрахунку вмісту олії у насінні за формулою (1) було виконано п'ять паралельних вимірювань. Вихідні дані для розрахунку вмісту олії у насінні наведені у табл. 1.

(C) І.П. Захаров, д.т.н., Т.В. Чуніхіна, к.т.н., В.Ю. Папченко, к.т.н. 
Таблиця 1

Результати вимірювання маси при реалізації паралельних вимірювань

\begin{tabular}{|c|c|}
\hline $\begin{array}{c}\text { Номер } \\
\text { паралельного } \\
\text { вимірювання }\end{array}$ & Результати вимірювання маси \\
\hline 1 & $\begin{array}{c}m=145,7984 \Gamma \\
m_{1}=143,4263 \Gamma \\
m_{2}=6,0612 \Gamma\end{array}$ \\
\hline 2 & $\begin{array}{c}m=104,8702 \Gamma \\
m_{1}=102,4981 \Gamma \\
m_{2}=5,9901 \Gamma\end{array}$ \\
\hline 3 & $\begin{array}{c}m=101,1455 \Gamma \\
m_{1}=98,7734 \Gamma \\
m_{2}=6,0205 \Gamma\end{array}$ \\
\hline 4 & $\begin{array}{c}m=115,6502 \Gamma \\
m_{1}=113,2781 \Gamma \\
m_{2}=6,0053 \Gamma\end{array}$ \\
\hline 5 & $\begin{array}{c}m=130,1158 \Gamma \\
m_{l}=127,7437 \Gamma \\
m_{2}=6,0358 \Gamma\end{array}$ \\
\hline
\end{tabular}

Отримані із використанням формули (1) результати вимірювання вмісту олії у насінні перераховуються на суху речовину за формулою [7]:

$$
X^{*}=\frac{X \cdot 100 \%}{100 \%-W}
$$

де $X$ - вміст олії в зразку насіння, \%; $W$ - масова частка вологи у зразку подрібненого насіння, \%.

Масова частка вологи в зразку насіння розраховується за формулою:

$$
W=\frac{\left(m-m_{1}\right)}{\left(m-m_{2}\right)} \cdot 100 \%,
$$

де $m$ - маса бюкси 3 насінням до висушення, г; $m_{l}$ - масса бюкси 3 насінням після висушення, г; $m_{2}$ - маса порожньої бюкси, г.

Вихідні дані для розрахунку масової частки вологи при реалізації двох паралельних вимірювань наступні: $m=15,8922 \Gamma, m_{l}=15,7945 \Gamma, m_{2}=12,5864$ г (перше вимірювання); $m=15,3618$ г, $m_{l}=15,2622$ г, $m_{2}=12,0321$ г (друге вимірювання).

Отримані значення масової частки вологи у зразку насіння при реалізації двох паралельних вимірювань: $W_{1}=2,955 \%, W_{2}=2,991 \%$.

Середньо-арифметичне значення масової частки вологи розраховувалося за формулою:

$$
\bar{W}=\frac{1}{2} \sum_{i=1}^{2} \frac{\left(m-m_{1}\right)}{\left(m-m_{2}\right)} \cdot 100 \%,
$$

де $m$ - маса бюкси 3 насінням до висушення, $г$; $m_{l}$ - масса бюкси 3 насінням після висушення, г; $m_{2}$ - маса порожньої бюкси, г.

Середньо-арифметичне значення масової частки вологи у зразку насіння склало $\bar{W}=2,9734 \%$.

Розрахунок середньо-арифметичного значення вмісту олії у насінні було здійснено за наступною формулою:

$$
\bar{X}^{*}=\frac{1}{5} \sum_{i=1}^{5} \frac{X_{i} \cdot 100 \%}{100 \%-\bar{W}}
$$

де $X_{i}$ - вміст олії в зразку насіння, \%; $\bar{W}$ - середньо-арифметичне значення масової частки вологи у зразку подрібненого насіння, \%.

(C) І.П. Захаров, д.т.н., Т.В. Чуніхіна, к.т.н., В.Ю. Папченко, к.т.н. 
Середньо-арифметичне значення вмісту олії у насінні склало $\bar{X}^{*}=40,607 \%$.

Результати вимірювання вмісту олії у насінні, розраховані із використанням формул (1) та (2), наведені у табл. 2.

Таблиця 2

Результати вимірювання вмісту олії у насінні

\begin{tabular}{|c|c|c|}
\hline \multirow{2}{*}{$\begin{array}{c}\text { Номер } \\
\text { паралельного } \\
\text { вимірювання }\end{array}$} & \multicolumn{2}{|c|}{ Результати вимірювання } \\
\cline { 2 - 3 } & $X_{i}, \boldsymbol{\%}$ & $X_{i}^{*}, \boldsymbol{\%}$ \\
\hline 1 & 39,2 & 40,40 \\
\hline 2 & 39,6 & 40,81 \\
\hline 3 & 39,4 & 40,61 \\
\hline 4 & 39,5 & 40,71 \\
\hline 5 & 39,3 & 40,50 \\
\hline
\end{tabular}

Розрахунок невизначеності вимірювання вмісту олії у насінні соняшника.

Вимірювання досліджуваних параметрів проводилися у нормальних умовах, тобто додаткові похибки були відсутні.

Вимоги щодо умов вимірювання показників якості насіння соняшника наступні: температура повітря $(20 \pm 5)^{0} C$; атмосферний тиск від $84,0 \times 10^{3}$ Па до $106,7 \times 10^{3}$ Па; відносна вологість повітря (за температури $25^{\circ} \mathrm{C}$ ) не повинна перевищувати $80 \%$.

Результати багаторазових вимірювань були використані для розрахунку стандартної невизначеності за типом А, паспортні дані приладів - для розрахунку стандартної невизначеності за типом В [11].

Розрахунок стандартної невизначеності за типом $\mathrm{A} u_{A}$ було здійснено із використанням наступної формули:

$$
u_{A \bar{x}}=\sqrt{\frac{1}{n(n-1)} \sum_{i=1}^{n}\left(x_{i}-\bar{x}\right)^{2}},
$$

де $\bar{x}$ - середньо-арифметичне значення результатів багаторазових вимірювань; $n$ - число багаторазових вимірювань.

Розрахунок стандартної невизначеності за типом В проводився за формулою:

$$
u_{B}=\frac{\Theta}{\sqrt{3}}
$$

де $\Theta$ - границі невиключеної систематичної похибки; $\sqrt{3}$ - коефіцієнт, пов'язаний із прямокутним розподілом щільності ймовірності.

Сумарна стандартна невизначеність вимірювання масової частки вологи у зразку подрібненого насіння визначається за формулою:

$$
u_{C}(\bar{W})=\sqrt{u_{B}^{2}(m) \sum_{i=1}^{2} C_{m i}^{2}+u_{B}^{2}(m) \sum_{i=1}^{2} C_{m l i}^{2}+u_{B}^{2}(m) \sum_{i=1}^{2} C_{m 2 i}^{2}+u_{A}^{2}(\bar{W})},
$$

де $C_{m_{i}}$ - коефіцієнти чутливості невизначеності вимірювання масової частки вологи до невизначеності вимірювання маси $m, m_{l}, m_{2} ; u_{B}(m)=\frac{0,0001}{\sqrt{3}} 2-$ стандартна невизначеність за типом В вимірювання маси; $u_{A}(\bar{W})$ - стандартна невизначеність за типом А вимірювання масової частки вологи.

Значення сумарної стандартної невизначеності вимірювання масової частки вологи у зразку подрібненого насіння становить $u_{C}(\bar{W})=0,01797 \%$.

Сумарна стандартна невизначеність вимірювання вмісту олії у зразку насіння визначається за формулою: 


$$
u_{C}\left(\bar{X}^{*}\right)=\sqrt{u_{A}^{2}\left(\bar{X}^{*}\right)+C_{\bar{W}}^{2} \cdot u_{C}^{2}(\bar{W})+u_{B}^{2}\left(X_{i}\right) \sum_{i=1}^{5} C_{X_{i}}^{2}},
$$

де $u_{A}\left(\bar{X}^{*}\right)$ - стандартна невизначеність за типом А вимірювання вмісту олії у зразку насіння у перерахунку на суху речовину, $\% ; C_{\bar{W}}, C_{X_{i}}$ - коефіцієнти чутливості невизначеності вимірювання вмісту олії у зразку насіння у перерахунку на суху речовину до невизначеності вимірювання масової частки вологи та вмісту олії; $u_{B}\left(X_{i}\right)=\frac{0,0001}{\sqrt{3}} 2-$ стандартна невизначеність за типом В вимірювання маси; $u_{C}(\bar{W})$ - сумарна стандартна невизначеність вимірювання масової частки вологи, \%.

Розрахунок стандартної невизначеності за типом А вимірювання вмісту олії у зразку насіння було проведено за наступною формулою:

$$
u_{A}\left(\bar{X}^{*}\right)=\sqrt{\frac{1}{n(n-1)} \sum_{i=1}^{n}\left(X_{i}^{*}-\bar{X}^{*}\right)^{2}},
$$

де $X_{i}^{*}$ - і-те значення результату вимірювання вмісту олії у насінні; $\bar{X}^{*}$ - середньоарифметичне значення вмісту олії у насінні; $n$ - число багаторазових вимірювань $(n=5)$.

Значення стандартної невизначеності за типом А вимірювання вмісту олії у зразку насіння дорівнює $u_{A}\left(\bar{X}^{*}\right)=0,07287 \%$.

Значення сумарної стандартної невизначеності вимірювання вмісту олії у зразку насіння склало $u_{C}\left(\bar{X}^{*}\right)=0,07329 \%$.

Розрахунок стандартної розширеної невизначеності вимірювання вмісту олії у зразку насіння було виконано за наступною формулою:

$$
U=k \cdot u_{C}\left(\bar{X}^{*}\right)
$$

де $k$ - коефіцієнт охоплення, який визначається як коефіцієнт Ст'юдента для довірчої ймовірності $P=0,95$ та ефективного числа ступенів вільності, яке розраховується за формулою Велча-Саттерствейта $[11] ; \quad u_{C}\left(\bar{X}^{*}\right)$ - сумарна стандартна невизначеність вимірювання вмісту олії у зразку насіння.

Розрахунок ефективного числа ступенів вільності було проведено із використанням формули Велча-Саттерствейта:

$$
v_{\mathrm{eff}}=\frac{u_{C}^{4}\left(\bar{X}^{*}\right)}{\frac{u_{A}^{4}\left(\bar{X}^{*}\right)}{n-1}+\frac{u_{C}^{4}(\bar{W}) \cdot C_{\bar{W}}^{4}}{v_{\mathrm{eff} \bar{W}}}},
$$

де $v_{\text {eff } \overline{\mathrm{w}}}-$ ефективне число ступенів вільності при вимірюванні масової частки вологи; $n$ - число багаторазових вимірювань вмісту олії у зразку насіння $(n=5) ; u_{C}\left(\bar{X}^{*}\right)$ - сумарна стандартна невизначеність вимірювання вмісту олії у зразку насіння; $u_{A}\left(\bar{X}^{*}\right)$ - стандартна невизначеність за типом А вимірювання вмісту олії у зразку насіння у перерахунку на суху речовину, \%; $u_{C}(\bar{W})$ - сумарна стандартна невизначеність вимірювання масової частки вологи, $\% ; C_{\bar{W}}-$ коефіцієнт чутливості невизначеності вимірювання вмісту олії у зразку насіння у перерахунку на суху речовину до невизначеності вимірювання масової частки вологи.

Розраховане значення ефективного числа ступенів вільності дорівнює $v_{\text {eff }}=4,09$. Використовуючи дані таблиці розподілу Ст'юдента, приймаємо ефективне число ступенів вільності $v_{\text {eff }}=4$. У цьому разі коефіцієнт Ст'юдента дорівнює $t_{0,95}=2,78$.

Ефективне число ступенів вільності при вимірюванні масової частки вологи $v_{\text {eff } \overline{\mathrm{w}}}$ визначалося за формулою: 


$$
v_{\text {eff } \overline{\mathrm{w}}}=\frac{u_{C}^{4}(\bar{W})}{\frac{u_{A}^{4}(\bar{W})}{n-1}} .
$$

Отримане із формули (11) ефективне число ступенів вільності при вимірюванні масової частки вологи становить $v_{\text {eff } \overline{\mathrm{w}}}=1,01$.

Визначена за формулою (9) стандартна розширена невизначеності вимірювання вмісту олії у зразку насіння склала $U=0,20 \%$.

Таким чином, результат вимірювання вмісту олії у зразку насіння нової лінії може бути записаний як:

$$
X^{*}=(40,61 \pm 0,20) \%, P=0,95 \text {. }
$$

\section{Висновки:}

1. У роботі представлено результати дослідження фізико-хімічних показників якості насіння соняшника нової лінії X 114 В.

2. Наведено розрахунок невизначеності вимірювання при дослідженнях показників якості i безпеки соняшникової олії на прикладі дослідження вмісту олії у насінні соняшника при реалізації методу екстракції.

3. Стандартна розширена невизначеність вимірювання вмісту олії у зразку насіння у перерахунку на суху речовину склала $U=0,20 \%$.

\section{Джерела інформації}

1. ДСТУ 4492:2005 Масло подсолнечное. Технические условия. Київ, Держпоживстандарт України, чинний від 01.01.2007.

2. ДСТУ 4603:2006 Олії. Методи визначення масової частки вологи та летких речовин. Київ, Держпоживстандарт України, чинний від 01.01.2008.

3. ДСТУ 7082:2009 Олії. Методи визначання масової частки фосфоровмісних речовин. Київ, Держпоживстандарт України, чинний від 01.01.2011.

4. ДСТУ 4350:2004 Олії. Методи визначання кислотного числа» (ISO 660:1996, NEQ). Київ, Держпоживстандарт України, чинний від 01.10.2005.

5. МВB 081/12-0243-05 Методика виконання вимірювання масової частки залишкових кількостей хлорорганічних пестицидів у жирових продуктах методом газорідинної хроматографії.

6. ДСТУ 4570:2006 Жири рослинні та олії. Метод визначання пероксидного числа. Київ, Держпоживстандарт України, чинний від 01.01.2008.

7. DSTU 7577: 2014 Насіння олійне. Визначення вмісту олії методом екстракції в апараті Сокслета. Київ, Держпоживстандарт України, чинний від 01.05.2015.

8. ДСТУ ISO/IEC 17025:2006 Національний стандарт України. Загальні вимоги до компетентності випробувальних та калібрувальних лабораторій.

9. Особенности оценивания неопределенности результатов параллельных измерений / И.П. Захаров, А.П. Сергиенко, М.П. Сергиенко //“Системи обробки інформації” Харків: Харківський університет Повітряних Сил імені Івана Кожедуба, - 2008 , Вип. 4(71), С. 34-37.

10. Оценка неопределенности измерения физико-химических показателей качества и безопасности подсолнечного масла / И.П.Захаров, Т.В. Чунихина, В.Ю. Папченко // "Системи обробки інформації” Харків: Харківський університет Повітряних Сил імені Івана Кожедуба, 2018 , Вип. 4(155), С. 109-113. Edition.

11. EURACHEM/CITAC Guide CG. Quantifying Uncertainty in. Analytical Measurement. Third

\section{${ }^{1}$ Захаров И. П., ${ }^{2}$ Чунихина Т. В., Папченко В. Ю.}

${ }^{1}$ Харьковский национальный университет радиоэлектроники

${ }^{2}$ Национальный технический университет "Харьковский политехнический институт"

${ }^{3}$ Украинский научно-исследовательский институт масел и жиров Национальной аграрной академии наук Украины 


\title{
ОЦЕНИВАНИЕ НЕОПРЕДЕЛЕННОСТИ ИЗМЕРЕНИЙ ПРИ ИССЛЕДОВАНИИ СЕМЕНА ПОДСОЛНЕЧНИКА НОВОЙ ЛИНИИ
}

\begin{abstract}
Масложировая отрасль является ведущей в пищевой промышленности Украины. Возрастающий за последние годы объем производства подсолнечного масла объясняется увеличением урожая и повышением содержания масла в семенах подсолнечника. В работе представлены результаты исследования физико-химических показателей качества семян подсолнечника новой линии. Детально рассмотрен процесс исследования одного из показателей качества, содержания масла в семенах подсолнечника, с использованием метода экстракиии. На примере одного из показателей качества, содержания масла в семенах подсолнечника, показан рассчет неопределенности измерения этого показателя.

Ключевые слова: семена подсолнечника, физико-химические показатели качества, метод экстракичи, параллельные измерения, неопределенность измерения.

${ }^{1}$ I. Zakharov, D.Sc., ${ }^{2}$ T. Chunikhina, C.Sc., ${ }^{3}$ V. Papchenko, C.Sc.

${ }^{1}$ Kharkiv National University of radioelectronics

${ }^{2}$ National Technical University "Kharkiv Polytechnic Institute"

${ }^{3}$ Ukrainian Scientific Research Institute of Oils and Fats of the National Academy of Agricultural

Sciences of Ukraine
\end{abstract}

\section{EVALUATION OF UNCERTAINTY OF MEASUREMENTS IN NEW LINE SUNFLOWER SEED RESEARCH}

Oil and fat industry is the main branch of the food industry in Ukraine. Increasing during the last few years volume of the production of the sunflower oil is caused by increase of the harvest and increase of the concentration of the oil in the sunflower seed. The results of the research of the quality of the sunflower seed of the new line are presented in the work. The process of the investigation of the one of the physical and chemical parameters of the quality of the sunflower seed, the concentration of the oil in the seed, was considered in detail. The example of the account of the uncertainty of the measurement of the concentration of the oil in the sunflower seed is given.

Keywords: the sunflower seed, physical and chemical parameters of the quality, extraction method, the parallel experiments, the uncertainty of the measurement. 